\title{
Dietary rambutan peel powder as a rumen modifier in beef cattle
}

\author{
Thiwakorn Ampapon ${ }^{1}$ and Metha Wanapat ${ }^{1}$ *
}

\begin{abstract}
* Corresponding Author: Metha Wanapat Tel: +66-81-9324180, Fax: +66-43-202368, E-mail: metha@kku.ac.th
\end{abstract}

${ }^{1}$ Tropical Feed Resources Research and Development Center (TROFREC), Department of Animal Science, Faculty of Agriculture, Khon Kaen University, Khon Kaen 40002, Thailand

ORCID

Thiwakorn Ampapon

https://orcid.org/0000-0002-5540-0939 Metha Wanapat

https://orcid.org/0000-0002-7633-052X

Submitted Apr 24, 2019; Revised Jun 3, 2019; Accepted Jul 6, 2019
Objective: The experiment was conducted to study the effect of rambutan (Nephelium lappaceum) fruit peel powder (RP) on feed consumption, digestibility of nutrients, ruminal fermentation dynamics and microbial population in Thai breed cattle.

Methods: Four, 2-year old ( $250 \pm 15 \mathrm{~kg}$ ) beef bull crossbreds $(75 \%$ Brahman $\times 25 \%$ local breed) were allotted to experimental treatments using a $4 \times 4$ Latin square design. Four dietary supplementation treatments were imposed; non-supplementation (control, T1); supplementation of RP fed at $2 \%$ of dry matter intake (DMI) (low, T2); supplementation of $\mathrm{RP}$ fed at $4 \%$ of DMI (medium, T3) and supplementation of RP fed at $\% \%$ of DMI (high, T4). All cattle were given a concentrate supplement at $1 \%$ of body weight while Napier grass was provided as a free choice.

Results: The findings revealed that RP supplementation did not negatively affect ( $p>0.05)$ DMI of Napier grass, while RP intake and total DMI were the greatest in the RP supplementation at $4 \%$ and $6 \%$ DMI. Nevertheless, the nutrients (dry matter, organic matter, crude protein, neutral detergent fiber, and acid detergent fiber) digestibilities were not changed in the RP supplementation groups. Rumen fermentation parameters especially those of total volatile fatty acids, acetate and butyrate were not significantly changed. However, the propionate concentration was remarkably increased $(\mathrm{p}<0.05)$ in the RP supplementation. Notably, the ratio of acetate to propionate, the number of protozoa, as well as the methane estimation were significantly reduced in the RP supplemented groups ( $4 \%$ and $6 \%$ of DMI), while the counts of bacteria was not altered.

Conclusion: Supplementation of RP ( $4 \%$ of DMI) improved rumen propionate production, reduced protozoal population and methane estimation $(\mathrm{p}<0.05)$ without a negative effect on feed consumption and nutrients total tract digestibilities in beef cattle. Using dietary rambutan fruit peel powder has potential promise as a rumen regulator.

Keywords: Methane; Plant Secondary Compounds; Rambutan Peel Powder; Rumen Enhancer

\section{INTRODUCTION}

Russell and Rychlick [1] stated the importance of rumen ecology on rumen fermentation efficiency and the subsequent production of livestock. The use of feed additives such as antibiotics can improve rumen fermentation efficiency. While, research and development regarding methane $\left(\mathrm{CH}_{4}\right)$ production in ruminants have been receiving considerable attention in which mitigation of the rumen $\mathrm{CH}_{4}$ has been the main issue [2]. The ruminal methane production is associated with global warming and the loss of digestible energy intake ( $8 \%$ to $12 \%$ of total energy intake) [3]. Currently, plants rich in plant metabolites (condensed tannins [CT], saponins [SP]) and essential oils have been receiving more interest regarding their selective inhibition of some rumen microbes and their fermentation [4]. Rambutan (Nephelium lappaceum) is a tropical fruit, grown in Southeast Asia e.g. Thailand, Malaysia, Indonesia, Vietnam and eaten fresh and can produce the products such as jams, juice and canned products. Rambutan peel s contains a high level of phenolic compounds such as 
tannins, SP, flavanoi, garaiin etc [5]. Locally available feed resources containing plant metabolites (polyphenols) especially those of anthrocyanidins and/or SP have been shown to increase the rumen propionate $\left(\mathrm{C}_{3}\right)$, decreased rumen degradation of protein, reducing $\mathrm{CH}_{4}$ production and increasing conjugated linoleic acid in ruminant products [6]. Therefore, rambutan peel powder (RP) is a potential supplement to manipulate the rumen process. Nevertheless, modification of rumen fermentation in ruminants by using RP containing CT and SP has been relatively limited. Plant secondary metabolites namely SP and tannins which can impact on rumen microorganisms and fermentation, increased total volatile fatty acid (VFA), supporting the ruminant hosts, whilst mitigating rumen methane production as stated by Poungchompu et al [7]. Hence, this experiment aimed at investigating the influence of RP levels on feed consumption, total tract nutrients digestibilities, rumen fermentation dynamics and methane production in Thai native cattle.

\section{MATERIALS AND METHODS}

\section{Feed preparation, experimental design of animals}

In brief, the RP was prepared as follows; the rambutan peels were collected from fresh fruit peel at Malee Group Public Company Limited in Nakhon Pathom province, Thailand. The peels were sun-dried for about 5 days to attain about $90 \%$ $\mathrm{DM}$ and ground into powder form. Feed ingredients and their nutritive values are presented in Table 1.

Table 1. Feed ingredients and chemical composition of the experimental diets

\begin{tabular}{lccc}
\hline Items & Concentrate & RP & Napier grass \\
\hline Ingredients (g/kg DM) & & & \\
Cassava chip & 600.0 & - & - \\
Rice bran & 100.0 & - & - \\
Coconut meal & 80.0 & - & - \\
Palm kernel meal & 80.0 & - & - \\
Soybean meal & 80.0 & - & - \\
Molasses & 15.0 & - & - \\
Urea & 30.0 & - & - \\
Mineral mixture & 5.0 & - & - \\
Salt & 5.0 & - & - \\
Sulfur & 5.0 & - & - \\
Chemical composition (g/kg DM) & & & \\
Dry matter & 877.0 & 887.0 & 302.0 \\
Organic matter & 926.0 & 966.0 & 914.0 \\
Ash & 74.0 & 34.0 & 86.0 \\
Crude protein & 141.0 & 44.0 & 102.0 \\
Neutral detergent fiber & 184.0 & 313.0 & 697.0 \\
Acid detergent fiber & 107.0 & 268.0 & 435.0 \\
Condensed tannins & - & 120.0 & - \\
Saponins & - & 105.0 & - \\
\hline
\end{tabular}

$\mathrm{RP}$, rambutan peel powder; DM, dry matter.
The study was conducted at the Tropical Feed Resources Research and Development Center (TROFREC), Department of Animal Science, Faculty of Agriculture, Khon Kaen University (KKU), Thailand. All procedures involving animals in the metabolism studies were approved by the Institutional Animal Care and Use Committee of Khon Kaen University (KKU) (Ref. no. AEKKU 18/2558).

Four, 2-year old $(250 \pm 15 \mathrm{~kg})$ crossbred beef cattle $(75 \%$ Brahman $\times 25 \%$ Thai native), were assigned to receive experimental diets in a $4 \times 4$ Latin square design. The dietary treatments were as follows; non-supplementation (T1); supplementation of RP fed at $2 \%$ of dry matter intake (DMI) (T2); supplementation of RP fed at $4 \%$ of DMI (T3) and supplementation of RP fed at $6 \%$ of DMI (T4), respectively. The experimental cattle were offered concentrate mixture at $1.0 \%$ of body weight (BW), fed two times a day, in the morning and in the afternoon, while Napier grass (Pak Chong I) was fed freely. Mineral blocks and water were provided as a free choice during which the animals were kept in individual pens. This experiment was conducted comprising of the preliminary and the actual feeding regimes for four periods, and each period lasted for 21 days. After the first 14 days, all beef cattle were well adjusted to dietary treatments and samples of the supplement and Napier grass including the left-over were collected, every day during the entire feeding periods. During the last 7 days, feeds and fecal were collected from each animal in the morning before feeding time $(07: 00 \mathrm{am})$ samples of feces $\mathrm{w}$ in each period. All samples were then composited for each animal period. They were stored in freezer until preparation for chemical analysis.

\section{Data collection, sample collection, and chemical analyses}

Feeds and fecal samples were analyzed for their chemical composition by the method of AOAC [8], neutral detergent fiber (NDF), acid detergent fiber (ADF) according to Van Soest et al [9] and acid-insoluble ash (AIA). The AIA was used as an internal indicator to predict the digestibility of nutrients as described by Van Keulen and Young [10]. Plant secondary metabolites especially proantrocyanidins or CTs were chemically analyzed by the Vanillin-HCL method [11] and SP using methanol extraction as described by Wanapat and Ngamsaeng [12].

Respective rumen fluid from each bull was sampled via stomach tube using vacuum pump to withdraw rumen fluid at $0,4 \mathrm{~h}$ post feeding. The rumen $\mathrm{pH}$ and temperature were immediately measured using the measurement meter (HANNA instrument HI 8424 microcomputer, Singapore). Respective samples of rumen fluid from treatments were then thoroughly filtered. The second portion of rumen fluid was then fixed with $10 \%$ formalin solution ( $1: 9 \mathrm{v} / \mathrm{v}$, rumen fluid: $10 \%$ formalin) for total direct counts of microorganisms (bacteria, 
protozoa, and fungal zoospores) by haemacytometer [13]. Samples were analyzed for rumen VFAs produced from rumen fermentation, for $\mathrm{NH}_{3}-\mathrm{N}$, where $5 \mathrm{~mL}$ of $\mathrm{H}_{2} \mathrm{SO}_{4}$ solution $(1 \mathrm{M})$ was added to $45 \mathrm{~mL}$ of rumen fluid. The mixture was centrifuged at $1,600 \times \mathrm{g}$ for $15 \mathrm{~min}$, and the supernatant was later stored at $-20^{\circ} \mathrm{C}$ prior to VFA analyses using high-performance liquid chromatography [14]. The blood sample from jugular vein, about $10 \mathrm{~mL}$, was collected into tubes with ethylenediaminetetraacetic acid, separated by centrifugation at $500 \times \mathrm{g}$ for $10 \mathrm{~min}$ at $4^{\circ} \mathrm{C}$ then the plasma was stored at $-20^{\circ} \mathrm{C}$ until later analysis of blood urea $\mathrm{N}$ according to the method of Crocker [15]. Details of the experimental protocols used under this experiment were fully reported in Wanapat et al [16].

The VFAs $\left(\mathrm{C}_{2}, \mathrm{C}_{3}, \mathrm{C}_{4}\right)$ were used in the equation as described by Moss et al [17] in order to predict the methane estimation.

$$
\begin{aligned}
\mathrm{CH}_{4} \text { estimation }= & 0.45\left(\text { acetate, } \mathrm{C}_{2}\right)-0.275\left(\text { propionate, } \mathrm{C}_{3}\right) \\
& +0.4\left(\text { butyrate }, \mathrm{C}_{4}\right)
\end{aligned}
$$

\section{Statistical analyses}

All the data were statistically analyzed using procedure general linear model (Statistical Analysis System [SAS], 2013) [18] according a $4 \times 4$ Latin square design. Treatment trends were statistically compared using orthogonal polynomials. The results were presented as mean values with the standard error of the means. Difference among means with $\mathrm{p}<0.05$ was accepted as statistical differences.

\section{RESULTS}

Experimental ingredients used in diets and their chemical analyzes

The composition of the concentrate, rambutan peel powder and Napier grass, are shown in Table 1 . The nutritive values of fibrous components (NDF, ADF), and crude protein (CP) were 184 and 107 and $141 \mathrm{~g} / \mathrm{kg}$ DM in the concentrate, respectively. Napier grass contained 102, 697, and 435 g/kg DM of $\mathrm{CP}, \mathrm{NDF}$, and $\mathrm{ADF}$, respectively. The rambutan peel powder contained 120 and $105 \mathrm{~g} / \mathrm{kg}$ DM of CTs and SP, respectively.

\section{Feed consumption and nutrients digestibilities}

The DMI measured by $\mathrm{kg} / \mathrm{d}$, \% BW/d, and $\mathrm{g} / \mathrm{kg} \mathrm{BW}^{0.75} / \mathrm{d}$ data are presented in Table 2. DM intake of Napier grass and concentrate were similar by RP supplementation. As shown, the DM of Napier grass ranged from 5.7 to $5.8 \mathrm{~kg} \mathrm{DM} / \mathrm{d}$, while the concentrate intakes were provided as $1 \%$ of BW. However, total DMI and DM intake of RP were linearly increased, while $\mathrm{CT}$ and SP intake were increased when RP was added at $2 \%$, $4 \%$, and $6 \%$ DMI. Furthermore, nutrient digestibilities were not affected by the RP supplementation except at the high level of RP (4\% and 6\% of DMI).

Ruminal fermentation, blood, methane estimation, and microbial population

Ruminal fermentation characteristics by supplementation of $\mathrm{RP}$ are shown in Table 3. The results of rumen $\mathrm{pH}$ (6.6 to 6.7), temperature $\left(39.0^{\circ} \mathrm{C}\right.$ to $\left.39.8^{\circ} \mathrm{C}\right)$ remained unchanged $(\mathrm{p}>$ 0.05). Rumen $\mathrm{NH}_{3}-\mathrm{N}$ (17.5 to $18.1 \mathrm{mg} / \mathrm{dL}$ ) and blood urea nitrogen (BUN) (9.7 to $10.4 \mathrm{mg} / \mathrm{dL}$ ) were not altered ( $p>0.05$ ). Furthermore, ruminal fermentation parameters (VFAs, $\mathrm{C}_{2}$, $\mathrm{C}_{4}$ ) were not significantly impacted by dietary treatments imposed. However, $\mathrm{C}_{3}$ was significantly increased in the $\mathrm{RP}$ supplementation at both $4 \%$ and $6 \%$ of DMI $(\mathrm{T} 3, \mathrm{~T} 4)$. Moreover, the $\mathrm{C}_{2}: \mathrm{C}_{3}$ ratio and methane estimation were significantly deceased in the supplementation at $4 \%, 6 \%$ of DMI $(\mathrm{T} 3, \mathrm{~T} 4)$. Nevertheless, the counts of total bacteria were not affected by RP the supplementation whilst, the number of protozoa was significantly reduced with an increased level of RP supplementation, meanwhile the number of fungal zoospores were similar in the RP supplementation groups.

\section{DISCUSSION}

\section{Feed consumption and digestibilities of nutrients}

Supplementation of RP did not change DMI of Napier grass, whilst the total DMI, RP intake, CT intake, and SP intake were linearly increased when RP was added at $2 \%, 4 \%$, and $6 \%$ DMI. However, the lack of effect on apparent digestibility under this experiment could be explained by the low concentration of CT in the supplementation levels used $(0 \%$, $2 \%, 4 \%, 6 \% \mathrm{DMI})$, which RP (6\% DMI) contained 0.7\% CT and $0.6 \%$ SP of DMI, while as reported by Beauchemin et al [19] higher concentrations of CT ( $>50 \mathrm{~g} / \mathrm{kg}$ DMI reduces DMI and digestibility. of Poungchompu et al [7], who used a higher level of CT ( $>3 \%$ CT of total DMI), also reported a decrease of DMI and digestibility. This could be attributed to its coating of feed particles and an effect on the cellular membrane of the rumen bacteria.

\section{Ruminal fermentation, blood, methane estimation, and microbial population}

Under this study, the rumen $\mathrm{pH}$, temperature and ruminal $\mathrm{NH}_{3}-\mathrm{N}$ were not affected in the RP supplemented groups. The rumen $\mathrm{pH}$ of 6.5 to 6.8 was suitable for the bacterial activity especially cellulolytic bacteria, whilst BUN concentrations did not differ among treatments [20]. Wanapat and Pimpa [21] who stated that rumen degradable protein in the form of rumen $\mathrm{NH}_{3}-\mathrm{N}$ was essentially to be used for rumen microbial protein production efficiency. The optimal concentration of rumen $\mathrm{NH}_{3}-\mathrm{N}$ ( 15 to $30 \mathrm{mg} / \mathrm{dL}$ ) required for digestion by microorganisms has been reported when the ruminants were fed on rice straw $[20,21]$. 
Table 2. Effect of rambutan peel powder on feed intake and apparent digestibility in beef cattle

\begin{tabular}{|c|c|c|c|c|c|c|c|}
\hline \multirow{2}{*}{ Items } & \multicolumn{4}{|c|}{ Supplementation level of RP ( $g / k g$ of DMI) } & \multirow{2}{*}{ SEM } & \multicolumn{2}{|c|}{ Contrasts } \\
\hline & 0 & 2 & 4 & 6 & & L & Q \\
\hline \multicolumn{8}{|l|}{ Napier grass (DM) } \\
\hline $\mathrm{kg} / \mathrm{d}$ & 5.7 & 5.8 & 5.8 & 5.8 & 0.03 & 0.484 & 0.293 \\
\hline$\%$ BW/d & 2.1 & 2.2 & 2.2 & 2.2 & 0.11 & 0.675 & 0.256 \\
\hline $\mathrm{g} / \mathrm{kg} \mathrm{BW}^{0.75}$ & 86.7 & 87.0 & 88.2 & 87.3 & 0.43 & 0.612 & 0.567 \\
\hline \multicolumn{8}{|l|}{ Concentrate intake } \\
\hline $\mathrm{kg} / \mathrm{d}$ & 2.6 & 2.6 & 2.7 & 2.6 & 0.11 & 0.328 & 0.193 \\
\hline$\%$ BW/d & 1.0 & 1.0 & 1.0 & 1.0 & 0.05 & 0.142 & 0.153 \\
\hline $\mathrm{g} / \mathrm{kg} \mathrm{BW} W^{0.75}$ & 40.1 & 40.0 & 40.4 & 40.2 & 0.27 & 0.167 & 0.351 \\
\hline \multicolumn{8}{|l|}{ RP intake } \\
\hline $\mathrm{kg} / \mathrm{d}$ & $0^{\mathrm{a}}$ & $0.17^{b}$ & $0.34^{c}$ & $0.51^{d}$ & 0.02 & 0.012 & 0.973 \\
\hline$\%$ BW/d & $0^{\mathrm{a}}$ & $0.06^{b}$ & $0.13^{c}$ & $0.19^{d}$ & 0.01 & 0.025 & 0.703 \\
\hline $\mathrm{g} / \mathrm{kg} \mathrm{BW}^{0.75}$ & $0^{\mathrm{a}}$ & $2.6^{b}$ & $5.2^{c}$ & $7.6^{d}$ & 0.05 & 0.011 & 0.545 \\
\hline \multicolumn{8}{|l|}{ Total DM intake } \\
\hline $\mathrm{kg} / \mathrm{d}$ & $8.3^{\mathrm{a}}$ & $8.5^{\mathrm{ab}}$ & $8.8^{b}$ & $8.9^{b}$ & 0.03 & 0.001 & 0.447 \\
\hline$\%$ BW/d & $3.1^{\mathrm{a}}$ & $3.2^{\mathrm{a}}$ & $3.3^{\mathrm{ab}}$ & $3.4^{b}$ & 0.04 & 0.002 & 0.732 \\
\hline $\mathrm{g} / \mathrm{kg} \mathrm{BW} 0.75$ & $126.8^{\mathrm{a}}$ & $129.6^{b}$ & $133.8^{c}$ & $135.1^{c}$ & 0.41 & 0.001 & 0.487 \\
\hline \multicolumn{8}{|l|}{ CT intake } \\
\hline $\mathrm{g} / \mathrm{d}$ & $0.0^{\mathrm{a}}$ & $20.2^{b}$ & $40.1^{c}$ & $61.2^{d}$ & 2.42 & 0.012 & 0.043 \\
\hline$\%$ total intake & $0.0^{\mathrm{a}}$ & $0.24^{b}$ & $0.47^{c}$ & $0.69^{d}$ & 0.06 & 0.001 & 0.011 \\
\hline \multicolumn{8}{|l|}{ SP intake } \\
\hline$g / d$ & $0.0^{\mathrm{a}}$ & $17.7^{\mathrm{b}}$ & $35.7^{c}$ & $53.6^{d}$ & 2.11 & 0.001 & 0.021 \\
\hline$\%$ total intake & $0.0^{\mathrm{a}}$ & $0.21^{b}$ & $0.41^{c}$ & $0.61^{d}$ & 0.05 & 0.001 & 0.001 \\
\hline \multicolumn{8}{|l|}{ Apparent digestibility (\%) } \\
\hline Dry matter & 65.1 & 65.7 & 66.3 & 64.9 & 0.52 & 0.162 & 0.457 \\
\hline Organic matter & 67.1 & 67.5 & 67.7 & 66.9 & 0.91 & 0.218 & 0.312 \\
\hline Crude protein & 65.9 & 66.1 & 66.7 & 66.1 & 0.32 & 0.112 & 0.178 \\
\hline Neutral detergent fiber & 73.2 & 73.5 & 73.1 & 72.8 & 0.64 & 0.231 & 0.732 \\
\hline Acid detergent fiber & 62.7 & 62.6 & 63.1 & 63.0 & 0.55 & 0.125 & 0.435 \\
\hline
\end{tabular}

RP, rambutan peel powder; DMI, dry matter intake; SEM, standard error of the mean; L, linear; Q, quadratic; DM, dry matter; BW, body weight; CT, condensed tannins; SP, saponins.

${ }^{a-d}$ Means in the same row with different superscripts differ $(p<0.05)$.

Table 3. Effect of rambutan peel powder on rumen fermentation and microbial population in beef cattle

\begin{tabular}{|c|c|c|c|c|c|c|c|}
\hline \multirow{2}{*}{ Items } & \multicolumn{4}{|c|}{ Supplementation level of RP ( $g / k g$ of DMI) } & \multirow{2}{*}{ SEM } & \multicolumn{2}{|c|}{ Contrasts } \\
\hline & 0 & 2 & 4 & 6 & & $\mathrm{~L}$ & Q \\
\hline Ruminal pH & 6.7 & 6.7 & 6.6 & 6.6 & 0.09 & 0.144 & 0.221 \\
\hline Ruminal $\mathrm{NH}_{3}-\mathrm{N}(\mathrm{mg} / \mathrm{dL})$ & 17.5 & 17.7 & 18.1 & 17.9 & 0.06 & 0.235 & 0.283 \\
\hline BUN (mg/dL) & 9.7 & 10.3 & 10.4 & 10.1 & 0.11 & 0.120 & 0.311 \\
\hline Total VFA (mmol/L) & 97.3 & 99.8 & 99.3 & 97.5 & 1.25 & 0.243 & 0.675 \\
\hline Acetic acid $\left(C_{2}\right)$ & 69.5 & 69.0 & 68.5 & 69.1 & 0.20 & 0.123 & 0.139 \\
\hline Propionic acid $\left(\mathrm{C}_{3}\right)$ & $18.7^{\mathrm{a}}$ & $18.9^{\mathrm{a}}$ & $20.9^{b}$ & $20.5^{b}$ & 0.15 & 0.013 & 0.421 \\
\hline Butyric acid $\left(\mathrm{C}_{4}\right)$ & 11.8 & 12.1 & 10.6 & 10.4 & 0.57 & 0.144 & 0.111 \\
\hline$C_{2}: C_{3}$ & $3.7^{\mathrm{a}}$ & $3.7^{\mathrm{a}}$ & $3.3^{b}$ & $3.4^{b}$ & 0.06 & 0.034 & 0.476 \\
\hline Methane estimation $(\mathrm{mM} / \mathrm{L})^{1)}$ & $30.9^{\mathrm{a}}$ & $30.7^{\mathrm{a}}$ & $29.3^{b}$ & $29.6^{b}$ & 0.16 & 0.021 & 0.121 \\
\hline \multicolumn{8}{|l|}{ Total direct counts } \\
\hline
\end{tabular}

RP, rambutan peel powder; DMI, dry matter intake; SEM, standard error of the mean; L, linear; Q, quadratic; BUN, blood urea nitrogen; VFA, volatile fatty acids.

1) Calculated according to Moss et al [17]. $\mathrm{CH}_{4}$ estimation $=0.45$ (acetate) -0.275 (propionate) +0.4 (butyrate).

a-d Means in the same row with different superscripts differ $(p<0.05)$. 
In this experiment, the ruminal fermentation parameters (total VFA, $\mathrm{C}_{2}$, and $\mathrm{C}_{4}$ ) remained similar by the RP supplementation, while the $\mathrm{C}_{3}$ production was increased in the $\mathrm{RP}$ supplemented groups. It could be due to the relationships with feed intake improvement and the rumen microorganism activity. The ratio of $\mathrm{C}_{2}: \mathrm{C}_{3}$ was reduced as a result of the $\mathrm{RP}$ supplementation groups, which agreed with the data of Foiklang et al [22] who revealed that using grape pomace powder (GPP) supplement remarkably increased the total VFA and $\mathrm{C}_{3}$ production, while rumen methane estimation was dramatically decreased in the supplemented treatments. Similarly, Gunun et al [23] also reported that $\mathrm{C}_{3}$ was increased, while $\mathrm{C}_{2}$ and $\mathrm{C}_{4}$ were similar when supplementing with plants containing of CT and SP less than 3\% of total DMI. Norrapoke et al [24] who found that dietary of mangosteen peel powder (MSP) enhanced total VFA concentration, increasing $\mathrm{C}_{3}$, reducing $\mathrm{C}_{2}: \mathrm{C}_{3}$ and methane production in the MSP supplementation in swamp buffaloes.

Under this experiment, the total bacterial and fungal zoospores were similar among treatments, while the number of protozoa was reduced in the RP supplementation ( $4 \%$ to $6 \%$ DMI) groups. Norrapoke et al [24] who used MSP pellet at $300 \mathrm{~g} / \mathrm{hd} / \mathrm{d}$ in dairy cows, found no influence on rumen bacterial and fungal zoospores. Rumen protozoa and methanogens have a symbiotic relationship, in using $\mathrm{CO}_{2}$ to produce methane, and the methanogens adhering to the protozoa were reported to be responsible for $9 \%$ to $37 \%$ of the methane emissions in cattle. Plant metabolic compounds, essentially SP and CTs, have been reported to suppress rumen $\mathrm{CH}_{4}$ production [2]. The influence of tannins on methane emission depends on fermentation of microbes and the enzymes secreted [25]. Plant secondary metabolites (CT and SP) have been shown to exert impact on activity of rumen methanogens and protozoa activities that would then limit the $\mathrm{H}_{2}$ availability for methanogenesis in the rumen [26]. Furthermore, plant secondary compounds were found to react on the sterols membrane of the protozoa [27]. The possible actions of $\mathrm{CT}$ in reducing methane production include the indirect effect on reducing $\mathrm{H}_{2}$ formation and the activity of protozoa and methanogens [28]. In the present experiment, the $t$ methane production and protozoal population were subsequently decreased while fungal zoospores were not affected by the RP supplementation. This agrees with Shokryzadan et al [29] who found that supplementation of MSP reduced the rumen microbial population, especially protozoa and methanogens, as well mitigating methane production in ruminants. Paengkoum et al [30] also found that using CTs extracted from mangosteen peel could reduce gas production and concentration of ruminal methane in an in vitro gas experiment. Methanogens and $\mathrm{CH}_{4}$ production were significantly decreased when the MSP supplementation level was increased, the least value was obtained at $300 \mathrm{~g} / \mathrm{d}$. During the rumen fermentation process, enteric $\mathrm{CH}_{4}$ is produced when the metabolic hydrogen produced by rumen cellulolytic bacteria reacted with $\mathrm{CO}_{2}$ [31]. Bhatta et al [3] explained that tannins considerably suppressed the rumen methane production by decreasing the protozoal population found in an in vitro study. While, Foiklang et al [22] discovered that supplementation of GPP could suppress protozoal populations and mitigate methane production in cattle. Similarly, Poungchompu et al [7] revealed that using 4\% of MSP as a supplement could decrease rumen protozoa and, hence reduced methane production, accordingly. Currently, Aditya [32] and Gunun et al [23] also reported that using rambutan peel powder at 16 to $20 \mathrm{mg}$, remarkably decreased methane concentration in in vitro gas kinetic experiment. These results reiterate the impact of CTs and SP on rumen fermentation and the end-products.

\section{CONCLUSION}

Under this experiment, it could be summarized that RP supplementation at $4 \%$ of the total DMI did not exert any effects on feed intake. However, ruminal propionate concentration was significantly enhanced, while $\mathrm{C}_{2}: \mathrm{C}_{3}$ ratio, methane estimation and protozoal population were dramatically reduced. This study suggested that RP would be a promising dietary rumen enhancer without an adverse effect on feed consumption and nutrients total tract digestibilities.

\section{CONFLICT OF INTEREST}

We certify that there is no conflict of interest with any financial organization regarding the material discussed in the manuscript.

\section{ACKNOWLEDGMENTS}

Special thanks are extended to Tropical Feed Resources Research and Development Center (TROFREC), Department of Animal Science, Faculty of Agriculture, Khon Kaen University, Khon Kaen, Thailand and the Thailand Research Fund (TRF) through the International Research Network (IRN) program (TRF-IRN57W0002) and the Royal Golden Jubilee program (TRF-RGJ 598001) for their kind support on research fund and facility.

\section{REFERENCES}

1. Russell JB, Rychlik JL. Factors that alter rumen microbial ecology. Science 2001;292(5519):1119-22. https://doi.org/10. 1126/science. 1058830

2. Hook SE, Wright ADG, McBride BW. Methanogens: Methane producers of the rumen and mitigation strategies. Arch 2010; 
Article ID 945785. https://doi.org/10.1155/2010/945785

3. Bhatta R. Reducing enteric methane emission using plant secondary metabolites. In: Sejian V, Gaughan J, Baumgard L, Prasad C, Editors. Climate change impact on livestock: adaptation and mitigation. New Delhi, India: Springer; 2015. pp. 273-84. https://doi.org/10.1007/978-81-322-2265-1_17

4. Wallace RJ, McEvan NR, McIntosh FM, Teferedegne B, Newbold CJ. Natural products as manipulators of rumen fermentation. Asian-Australas J Anim Sci 2002;15:1458-68. https:// doi.org/10.5713/ajas.2002.1458

5. Sun L, Zhang H, Zhuang Y. Preparation of free, soluble conjugate, and insoluble-bound phenolic compounds from peels of rambutan (Nephelium lappaceum) and evaluation of antioxidant activities in vitro. J Food Sci 2012;77:C198-204. https:// doi.org/10.1111/j.1750-3841.2011.02548.x

6. Cieslak A, Szumacher-Strabel M, Stochmal A, Oleszek W. Plant components with specific activities against rumen methanogens. Animal 2013;7(S2):253-65. https://doi.org/10.1017/ S1751731113000852

7. Poungchompu O, Wanapat M, Wachirapakorn C, Wanapat $\mathrm{S}$, Cherdthong A. Manipulation of ruminal fermentation and methane production by dietary saponins and tannins from mangosteen peel and soapberry fruit. Arch Anim Nutr 2009; 63:389-400. https://doi.org/10.1080/17450390903020406

8. AOAC. Official Methods of Analysis. 19th ed. Gaithersburg, MD, USA: Association of Official Analytical Chemists; 2012.

9. Van Soest PJ, Robertson JB, Lewis BA. Methods for dietary fiber, neutral detergent fiber, and nonstarch polysaccharides in relation to animal nutrition. J Dairy Sci 1991;74:3583-97. https://doi.org/10.3168/jds.s0022-0302(91)78551-2

10. Van Keulen J, Young BA. Evaluation of Acid-Insoluble Ash as a Natural Marker in Ruminant Digestibility Studies. J Anim Sci 1977;44:282-7. https://doi.org/10.2527/jas1977.442282x

11. Wanapat M, Poungchompu O. Method for estimation of tannin by vanillin-HCL method (A Modified Method of Burns, 1971). Khon Kaen, Thailand: Department of Animal Science, Khon Kaen University; 2001.

12. Wanapat M, Ngamsaeng A. Method for estimation of crude saponins (A Modified Method of Kwon et al., 2003). Khon Kaen, Thailand: Department of Animal Science, Khon Kaen University; 2004.

13. Galyean M. Laboratory procedure in animal nutrition research. Las Cruces, NM, USA: Department of Animal and Range Sciences, New Mexico State University; 1989.

14. Samuel M, Sagathewan S, Thomas J, Mathen G. An HPLC method for estimation of volatile fatty acids of ruminal fluid. Indian J Anim Sci 1997;67:805-7.

15. Crocker CL. Rapid determination of urea nitrogen in serum or plasma without deproteinization. Am J Med Technol 1967; 33:361-5.

16. Wanapat M, Gunun P, Anantasook N, Kang S. Changes of rumen $\mathrm{pH}$, fermentation and microbial population as influ- enced by different ratios of roughage (rice straw) to concentrate in dairy steers. J Agric Sci 2014;152:675-85. https://doi.org/ $10.1017 /$ S0021859613000658

17. Moss AR, Jouany JP, Newbold J. Methane production by ruminants: its contribution to global warming. Ann Zootech 2000; 49:231-53. https://doi.org/10.1051/animres:2000119

18.SAS (Statistical Analysis System). User's guide: Statistic, Version 9.3th Edition. Cary, NC, USA: SAS Inst. Inc.; 2013.

19. Beauchemin KA, Kreuzer M, O’Mara F, McAllister TA. Nutritional management for enteric methane abatement: a review. Aust J Exp Agric 2008;48:21-7. https://doi.org/10.1071/EA 07199

20. Van Soest PJ, Robertson JBA. Laboratory manual for animal science. Ithaca, NY, USA: Cornell University Press; 1985.

21. Wanapat M, Pimpa O. Effect of ruminal NH3-N levels on ruminal fermentation, purine derivatives, digestibility and rice straw intake in swamp buffaloes. Asian-Australas J Anim Sci 1999;12:904-7. https://doi.org/10.5713/ajas.1999.904

22. Foiklang S, Wanapat M, Norrapoke T. In vitro rumen fermentation and digestibility of buffaloes as influenced by grape pomace powder and urea treated rice straw supplementation. Anim Sci J 2016;87:370-7. https://doi.org/10.1111/asj.12428

23. Gunun P, Gunun N, Cherdthong A, et al. In vitro rumen fermentation and methane production as affected by rambutan peel powder. J Appl Anim Res 2018;46:626-31. https://doi.org/ 10.1080/09712119.2017.1371608

24. Norrapoke T, Wanapat M, Wanapat S. Effects of protein level and mangosteen peel pellets (Mago-pel) in concentrate diets on rumen fermentation and milk production in lactating dairy crossbreds. Asian-Australas J Anim Sci 2012;25:9719. https://doi.org/10.5713/ajas.2012.12053

25. Baruah L, Malik PK, Kolte AP, Dhali A, Bhatta R. Methane mitigation potential of phyto-sources from Northeast India and their effect on rumen fermentation characteristics and protozoa in vitro. Vet World 2018;11:809-18. https:/doi.org/ 10.14202/vetworld.2018.809-818

26. Haque MN. Dietary manipulation: a sustainable way to mitigate methane emissions from ruminants. J Anim Sci Technol 2018;60:15. https://doi.org/10.1186/s40781-018-0175-7

27. Goel G, Makkar HPS. Methane mitigation from ruminants using tannins and saponins. Trop Anim Health Prod 2012; 44:729-39. https://doi.org/10.1007/s11250-011-9966-2

28. Tedeschi LO, Ramírez-Restrepo CA, Muir JP. Developing a conceptual model of possible benefits of condensed tannins for ruminant production. Animal 2014;8:1095-105. https:// doi.org/10.1017/S1751731114000974

29. Shokryzadan P, Rajion MA, Goh YM, et al. Mangosteen peel can reduce methane production and rumen biohydrogenation in vitro. S Afr J Anim Sci 2016;46:419-31. http://dx.doi. org/10.4314/sajas.v46i4.10

30.Paengkoum P, Phonmun T, Liang JB, Huang XD, Tan HY, Jahromi MF. Molecular weight, protein binding affinity and 
methane mitigation of condensed tannins from mangosteenpeel (Garcinia mangostana L). Asian-Australas J Animal Sci 2015;28:1442-8. https://doi.org/10.5713/ajas.13.0834

31.Polyorach S, Wanapat M, Cherdthong A, Kang S. Rumen microorganisms, methane production, and microbial protein synthesis affected by mangosteen peel powder supplement in lactating dairy cows. Trop Anim Health Prod 2016;48:593-
601. https://doi.org/10.1007/s11250-016-1004-y 32. Aditya S. The effect of rambutan peel (Nephelium lappaceum) as reducing agent on in vitro methane production within creating environment friendly farming. In: Köfer J, Schobesberger $\mathrm{H}$, editors. Animal hygiene and sustainable livestock production. Proc XVth Int Congr Anim Hygiene 2011 July; 3-7; Vienna, Austria. 